\title{
Pakan suspensi daging kekerangan bagi pertumbuhan benih sidat (Anguilla bicolor)
}

(Mussel flesh suspension food for growth of elver, Anguilla bicolor)

\section{P. A. Koroh, Cyska Lumenta}

\begin{abstract}
The objective of this research was to evaluate the effect of different mussel flesh suspension feed in providing best growth and feed efficiency on eel seeds, Anguilla bicolor. Treatment feed included A (kijing Taiwan Anodonta woodiana Lea)), B (keong mas Pomacea canaliculata), C (kerang darah Anadara granosa) and D (commercial pellet), each with three replications. Elver was reared in plastic container having diameter of $40 \mathrm{~cm}$. Research results showed the best relative growth and feed efficiency were achieved in treatment A with relative growth $64.95 \%$ and feed efficiency 4.41, followed by treatment $C$ (relative growth $40.97 \%$ and feed efficiency 2.73), Treatment D (relative growth $32.71 \% \%$ and feed efficiency 2.23), and treatment B (relative growth $31.61 \%$ and feed efficiency 2.17). During the experiment, water temperature was $26-28^{\circ} \mathrm{C}$ and $\mathrm{pH}$ 7 which were suitable for growth and survival of eel seeds. As conclusion, the use of suspension food of kijing taiwan mussel resulted in the best relative growth and food efficiency.
\end{abstract}

Keywords: elver, fish feed, mussel, growth, food efficiency

\section{PENDAHULUAN}

Sidat merupakan jenis komoditi eksport bernilai ekonomis penting yang mampu bersaing dengan jenis komoditi lainnya di pasaran internasional untuk menghasilkan devisa negara. Permintaan pasar dunia akan sidat semakin populer, menyebabkan harga jual sidat semakin mahal. Kandungan protein yang tinggi dan cita rasa daging sidat yang enak banyak dikonsumsi oleh masyarakat negara - negara maju seperti Jepang dan Hongkong sehingga sidat telah dibudidayakan secara intensif (Sarwono, 1997).

Sulistijo (1981) menyatakan bahwa potensi sumberdaya alam sidat yang dimiliki indonesia belum sepenuhnya dimanfaatkan baik dalam usaha penangkapan sidat (dewasa maupun elver) maupun untuk usaha budidaya. Potensi sidat yang belum tergarap secara optimal dapat digunakan untuk mendukung kecukupan protein dalam negeri selain untuk kepentingan eksport daerah yang potensial.
Pemeliharaan benih sidat dari alam di Sulawesi Utara baru pada tahap uji coba di laboratorium. Karena dengan pertimbangan membesarkan benih sidat hasil seleksi alam penuh resiko, sehingga perlu penerapan teknologi budidaya yang tepat untuk mengantisipasi kendala-kendala yang dihadapi (Sulistijo, 1981).

Upaya pengembangan budidaya sidat secara intensif, penyediaan benih yang berkualitas dalam jumlah besar dan secara terus menerus merupakan faktor yang penting. Selain itu kualtas air, pakan, penanggulangan penyakit dan penerapan teknologi budidaya yang tepat juga perlu diperhatikan (Matsui, 1986).

Faktor pakan merupakan hal yang amat menentukan dalam masa pemeliharaan. Bila pakan yang diberikan dalam jumlah cukup dan bermutu baik maka sangat akan membantu pertumbuhan, daya tahan terhadap serangan penyakit atau parasit. Begitu juga 
jenis pakan yang diberikan amat berperan dalam menentukan kualitas dan rasa daging sidat (Sarwono, 1987).

Menurut Matsui (1986), pakan yang baik bagi sidat adalah pakan daging segar berasal dari ikan, krustasea dan kekerangan. Sedangkan untuk benih sidat yang baru ditangkap dari alam biasanya diberikan pakan berbentuk pasta. Pakan berbentuk pasta dibuat dari cincangan daging kekerangan atau cacing yang telah dilumatkan menjadi bubur.

Kekerangan merupakan salah satu sumber protein hewani yang dapat dijadikan pakan dalam bentuk pasta. Kekerangan yang belum dimanfaatkan secara optimal dan belum memiliki nilai ekonomis penting yang berasal dari perairan tawar antara lain Kijing Taiwan dan Keong Emas. Sedangkan kerang darah merupakan jenis kerang yang berasal dari laut yang mudah ditemukan di pasaran. Kijing Taiwan di danau Tondano ketersediaannya cukup tersedia dan belum dimanfaatkan oleh masyarakat. Keong emas merupakan hama bagi tanaman padi, selada, sawi dan pisang muda (Anonim, 1993).

Berdasarkan beberapa pertimbangan di atas, maka dalam rangka pemanfaatan daging kekerangan sebagai pakan biota air khususnya sidat, maka pakan suspensi daging kekerangan ini akan diuji cobakan pada benih sidat, dalam hal ini untuk menelaah pengaruh pakan suspensi daging kekerangan terhadap pertumbuhan sidat dan nilai efisiensi pakan. Tujuan Penelitian ini adalah untuk menelaah pengaruh pemberian pakan suspensi daging kekerangan dalam memberikan respon yang paling baik bagi pertumbuhan maupun nilai efisiensi pakan sidat. Penelitian dilaksanakan di Laboratorium Nurisi dan Teknologi Budidaya Perairan Fakultas Perikanan dan Ilmu Kelautan UNSRAT Manado. Waktu pelaksanaan penelitian selama delapan minggu.

\section{METODE PENELITIAN}

\section{Tahap Persiapan}

\section{A. Persiapan Wadah dan Alat}

Wadah yang digunakan untuk pemeliharaan ikan uji adalah loyang plastik dngan diameter $40 \mathrm{~cm}$ sebanyak 12 buah untuk 4 perlakuan dan 3 ulangan. Wadah untuk penampungan air sebanyak 2 buah, Thermometer $\left({ }^{\circ} \mathrm{C}\right)$ untuk mengukur suhu, kertas indikator untuk mengukur $\mathrm{pH}$ air, 3 buah aerator sebagai sumber oksigen, selang plastik lain untuk menyipon sisa pakan dan kotoran lainnya. Timbangan ohaus dengan ketelitian 0,01 g untuk menimbang sidat dan pakan uji, blender untuk menghancurkan daging dan lemari es untuk menyimpan pakan suspensi daging kekerangan.

\section{B. Persiapan Ikan Uji}

Penyediaan ikan uji meliputi pengambilan benih sidat di muara sungai Poigar yang terletak di perbatasan Kabupaten Minahasa dan Kabupaten Bolaang Mongondow. Cara menangkap benih sidat dengan memakai alat handy scoop net (jaring halus), yang ditarik horizontal di sepanjang muara sungai Poigar. Benih sidat yang tertangkap ditampung dalam ember yang diberi aerator untuk mensuplai oksigen, selanjutnya dengan menggunakan mobil benih sidat di bawah ke laboratorium. Di laboratorium benih sidat diaklimatisasi selama 2 minggu untuk penyesuaian dengan lingkungan tempat percobaan dan pakan yang diuji cobakan.

\section{Persiapan Pakan Uji}

Pakan uji yang digunakan adalah daging kerang darah, keong emas, kijing Taiwan dan 
pellet komersil merek Bintang. Hasil analisis elemen nutrisinya disajikan pada Tabel 01. Cara pembuatan pakan semua daging kerang direbus sampai airnya mendidih, setelah itu daging kerang dimasukkan ke dalam blender dan dihancurkan sampai berbentuk suspensi. Pakan daging yang telah dihancurkan disimpan dalam lemari es untuk menjaga agar pakan tidak cepat membusuk.

\section{Tahap Pelaksanaan}

Percobaan dilakukan dengan mengisi setiap wadah dengan 10 liter air dan masing masing ditebari dengan 15 ekor sidat, berat rata - rata $0.08 \mathrm{~g}$ yang semuanya telah diaklimatisasi terlebih dahulu.

Frekuensi pemberian pakan sebanyak 3 kali sehari yaitu setiap jam 08.00, jam 13.00 dan jam 18.00, dengan jumlah pemberian pakan setiap hari 25\% dari berat tubuh ikan uji. Setiap pemberian pakan baru dilakukan penyiponan terlebih dahulu terhadap sisa pakan dan feses. Penimbangan sidat dilakukan dua minggu sekali.

Selanjutnya demi terkontrolnya kualitas air, dilakukan penggantian air setiap 3 hari disertai dengan pengukuran suhu dan $\mathrm{pH}$ air. Untuk pengukuran suhu dilakukan 3 kali sehari yaitu pagi, siang, dan malam hari dengann menggunakan thermometer celcius. Sedangkan pengukuran $\mathrm{pH}$ dilakukan sebelum dan sesudah air diganti dengan menggunakan kertas $\mathrm{pH}$.

\section{Rancangan Penelitian}

Sesuai dengan tujuan yang telah ditetapkan maka penelitian dilakukan dengan mengikuti rancangan - rancangan sebagai berikut :

\section{A. Rancangan Pelakuan}

Ada empat perlakuan dan masing masing perlakuan diulang sebanyak tiga kali. Perlakuan yang dicobakan adalah sebagai berikut :

- Perlakuan A, Pemberian pakan suspensi daging kijing Taiwan

- Perlakuan B, Pemberian pakan suspensi daging keong emas

- Perlakuan C, Pemberian pakan suspensi daging kerang darah

- Perlakuan D, Pemberian pakan komersil

Tabel 1. Nilai nutrisi pakan uji

\begin{tabular}{|c|c|c|c|c|}
\hline Nilai Nutrisi & $\begin{array}{l}\text { Pakan A } \\
\text { Kijing Taiwan }\end{array}$ & $\begin{array}{l}\text { Pakan B } \\
\text { Keong Emas }\end{array}$ & $\begin{array}{l}\text { Pakan C } \\
\text { Kerang Darah }\end{array}$ & $\begin{array}{l}\text { Pakan D } \\
\text { Pellet Komersil }\end{array}$ \\
\hline Protein (\%) & 12.20 & 9.50 & 10.05 & 69 \\
\hline Lemak (\%) & 0.33 & 3.17 & 0.35 & 6 \\
\hline Karbohirat (\%) & 3.90 & 3.23 & 4.14 & 38 \\
\hline Kadar Abu (\%) & 0.19 & 2.99 & 0.62 & 6 \\
\hline Kadar Air (\%) & 83.73 & 80.99 & 84.69 & 14 \\
\hline Serat Kasar (\%) & 0.08 & 0.12 & 0.15 & 7 \\
\hline Energi (Kkal) & 2761 & 1144 & 2707 & 2750 \\
\hline
\end{tabular}

Sumber : Data Analisis Kimiawi Lab. Pusat UNSRAT

\section{B. Rancangan Lingkungan}

Rancangan yang digunakan dalam penelitian adalah Rancangan Acak Lengkap
(RAL) dengan asumsi bahwa seluruh satuan percobaan dianggap homogen. Dan untuk analisis datanya menggunakan analisis ragam. 


\section{Rancangan Respon}

Parameter yang diukur yaitu pertambahan berat badan ikan dan nilai efisiensi pakan. Dalam hal ini jenis pertumbuhan yang dihitung adalah pertumbuhan nisbi.

Adapun rumus menghitung pertumbuhan nisbi dan nilai efisiensi pakan adalah sebagai berikut :

$$
G R(\%)=\frac{W_{t}-W_{0}}{W_{0}} \times 100
$$

Dimana, GR (\%) = Pertumbuhan nisbi

$\mathrm{W}_{\mathrm{t}}=$ Bobot badan ikan pada akhir perobaan

$\mathrm{W}_{\mathrm{o}}=$ Bobot badan ikan pada awal percobaan

Nilai Efisiensi Pakan (Pascual, 1994)

$$
\operatorname{NEP}(\%)=\frac{W_{t}-W_{0}}{F} X 100
$$

Dimana:

NEP (\%) = Nilai Efisiensi Pakan

Wt = Bobot ikan uji pada akhir percobaan

Wo $=$ Bobot ikan uji pada awal perobaan

$\mathrm{F} \quad=$ Jumlah pakan yang dikonsumsi selama penelitian

\section{HASIL DAN PEMBAHASAN}

\section{Pertumbuhan Nisbi}

Dari hasil perhitungan pada Tabel 2, terlihat bahwa pertumbuhan nisbi rataan benih sidat yang tertinggi adalah pada perlakuan A(67,95 \%), C(40.97\%), D (32.71 \%) dan B (31.61\%). Untuk mengetahui pengaruh perlakuan terhadap pertumbuhan nisbi, maka dilakukan analisis ragam yang hasil perhitungannya dapat dilihat pada Tabel 3.

Tabel 2. Pertumbuhan nisbi (\%) benih sidat pada setiap perlakuan yang diuji cobakan

\begin{tabular}{lllllll}
\hline \multirow{2}{*}{ Perlakuan } & $\begin{array}{c}\text { Pengamatan } \\
\text { Per 2 } \\
\text { Minggu }\end{array}$ & \multicolumn{5}{c}{ Ulangan } \\
\cline { 3 - 5 } & \multicolumn{2}{c}{1} & 2 & 3 & Jumlah & Rataan \\
\hline A & 2 & 24.10 & 17.11 & 17.31 & 58.52 & 19.51 \\
& 4 & 39.47 & 34.04 & 32.91 & 106.42 & 35.48 \\
& 6 & 55.26 & 50.89 & 48.93 & 155.09 & 51.70 \\
& 8 & 71.39 & 66.89 & 65.56 & 203.84 & 67.95 \\
B & 2 & 8.58 & 7.82 & 7.56 & 23.97 & 7.99 \\
& 4 & 16.99 & 15.48 & 15.04 & 47.51 & 15.84 \\
& 6 & 25.32 & 23.38 & 22.52 & 71.22 & 23.74 \\
C & 8 & 33.39 & 31.04 & 30.42 & 94.84 & 31.61 \\
& 2 & 8.66 & 11.33 & 10.78 & 30.77 & 10.26 \\
& 4 & 17.15 & 22.66 & 21.39 & 61.20 & 20.40 \\
& 6 & 25.89 & 34.24 & 32.00 & 92.14 & 30.71 \\
D & 8 & 34.81 & 45.66 & 42.45 & 122.91 & 40.97 \\
& 2 & 9.44 & 9.02 & 9.65 & 28.11 & 9.37 \\
& 4 & 17.01 & 16.51 & 18.02 & 51.54 & 17.18 \\
& 6 & 24.32 & 24.00 & 26.47 & 74.79 & 24.93 \\
\hline Total & 8 & 31.46 & 31.66 & 35.01 & 98.14 & 32.71 \\
\hline
\end{tabular}


Tabel 3. Analisis ragam pengaruh perlakuan terhadap pertumbuhan nisbi

\begin{tabular}{|c|c|c|c|c|c|c|}
\hline \multirow{2}{*}{$\begin{array}{c}\text { Sumber } \\
\text { Keragaman }\end{array}$} & \multirow{2}{*}{ DB } & \multirow{2}{*}{ JK } & \multirow{2}{*}{$\mathrm{KT}$} & \multirow{2}{*}{ F hitung } & \multicolumn{2}{|c|}{$\mathrm{F}_{\text {Tabel }}$} \\
\hline & & & & & $5 \%$ & $1 \%$ \\
\hline Perlakuan & $4-1=3$ & 2584.86 & 861.62 & $73.56 * *$ & 4.07 & 7.59 \\
\hline Galat & $4(3-1)=8$ & 93.71 & 11.71 & T.50 & 4.07 & כט. \\
\hline Total & 11 & 2678.57 & & & & \\
\hline
\end{tabular}

Ket : ** Sangat nyata

Hasil analisis keragaman memperlihatkan bahwa semua perlakuan memberikan pengaruh yang sangat nyata terhadap pertumbuhan nisbi. Hal ini jelas terlihat pada $F_{\text {hitung }}$ lebih besar $F_{\text {tabel }}$ baik pada tahap 0.05 maupun taraf 0.01. Sebagai uji lanjut untuk mengetahui perlakuan mana yang tampil lebih baik dilakukan uji jarak berganda Duncan.

Dengan melihat hasil perbandingan nilai uji jarak berganda Duncan menunjukkan bahwa perlakuan B tidak berbeda nyata dengan perlakuan D. Perlakuan D berbeda nyata degan perlakuan C. Sedangkan perlakuan A berbeda sangat nyata dengan perlakuan C, D, B.

\section{Nilai Efisiensi Pakan}

Tabel 4. Nilai Efisiensi Pakan (\%) dari Setiap Perlakuan

\begin{tabular}{lccccc}
\hline \multirow{2}{*}{ Ulangan } & \multicolumn{5}{c}{ PERLAKUAN } \\
\cline { 2 - 5 } & $\mathrm{A}$ & $\mathrm{B}$ & $\mathrm{C}$ & $\mathrm{D}$ & \\
\hline 1 & 4.23 & 2.28 & 2.37 & 2.15 & \\
2 & 4.99 & 2.14 & 3.00 & 2.17 & \\
3 & 4.01 & 2.81 & 2.81 & 2.37 & \\
\hline Jumlah & 13.23 & 6.52 & 8.18 & 6.69 & 34.62 \\
\hline Rataan & 4.41 & 2.17 & 2.73 & 2.23 & \\
\hline
\end{tabular}

Berdasarkan Tabel 04 di atas terlihat bahwa hasil perhitungan nilai efisiensi pakan yang tertinggi pada perlakuan A pakan suspensi daging kijing Taiwan (4.41\%), kemudian diikuti perlakuan $\mathrm{C}$ pakan suspensi daging kerang darah (2.73\%), D pakan komersil (2.23\%), dan B pakan suspensi daging keong emas (2.17\%).

Untuk mengetahui pengaruh perlakuan terhadap nilai efisiensi pakan selama percobaan dapat dilihat pada Tabel 5.

Tabel 5. Analisis ragam pengaruh perlakuan terhadap efisiensi pakan selama percobaan

\begin{tabular}{lcccc}
\hline $\begin{array}{c}\text { Sumber } \\
\text { Keragaman }\end{array}$ & DB & JK & KT & $F_{\text {hitung }}$ \\
\hline Perlakuan & $4-1=3$ & 9.88 & 3.29 & \\
Galat & $4(3-1)=$ & 0.78 & 0.10 & $33.61^{* *}$ \\
& 8 & & \\
\hline Total & & & \\
\hline Keterangan : **Sangat nyata &
\end{tabular}

Selanjutnya dari hasil analisis ragam nilai efisiensi pakan dari semua perlakuan berpengaruh sangat nyata, dimana $F_{\text {hitung }}$ lebih besar $F_{\text {tabel }}$ baik pada tahap 0.05 maupun taraf 0.01 . Untuk mengetahui perlakuan mana yang terbaik dilakukan uji berganda Duncan. Setelah diadakan pengujian jarak berganda Duncan, maka diperoleh perbandingan nilai rataan yang menunjukkan bahwa perlakuan $\mathrm{A}$ berbeda sangat nyata dengan perlakuan $\mathrm{C}, \mathrm{D}$, $\mathrm{B}$, sedangkan perlakuan $\mathrm{D}$ tidak berbeda nyata dengan perlakuan C dan B. Pakan suspensi memenuhi persyaratan pakan yang sesuai dengan kebutuhan sidat sehingga dapat dimanfaatkan dengan baik untuk menunjang pertumbuhan. 
Berdasarkan hasil nilai rataan baik pertumbuhan nisbi dan nilai efisiesi pakan diperoleh bahwa memberikan respon terbaik. Pertumbuhan nisbi yang dicapai oleh perlakuan A dengan bahan dasar suspensi daging kerang $(67,45 \%)$ dan nilai efisiensi pakan (4,41\%). Pakan suspensi daging kijing taiwan memiliki keunggulan dibandingkan dengan pakan lain yang diujicobakan. Saat pengolahan dan pembuatan pakan nampak jelas bahwa karakteristik daging kijing taiwan mudah diolah karena tekstur dagingnya lebih lembut sehingga cepat lumat dibandingkan tekstur daging pakan keong emas dan kerang darah Mengandung protein(12,20 \%) ditunjukan Tabel 01 lebih tinggi kandungan proteinnya daripada pakan yang lain, juga memiliki daya atraktan yang disenangi benih sidat.

Walaupun pakan komersil memliki kandungan protein sebesar 69\% namun karena penampilan fisik pakannya kasar dan tidak memiliki keragaman butiran bahan seperti yang ditampilkan oleh pakan suspensi daging kijing Taiwan sehingga tidak memacu pertumbuhan dan nilai efiesinsi pakan benih sidat dengan baik. Sandiver dan Yosep (1976), menyatakan bahwa adanya kandungan protein yang tinggi dalam pakan tidak selamanya menjamin pertumbuhan yang baik. Secara jelas dinyatakan pula bahwa pakan tidak hanya ditentukan oleh kandungan protein yang tinggi, tetapi juga oleh elemen nutrisi pendukung lainnya seperti lemak, karbohidrat, vitamin, dan mineral semua ini diperlukan untuk kesehatan ikan dan pertumbuhan.Pertumbuhan akan terjadi ketika ikan mampu mengkonsumsi pakan setiap harinya akan mempengaruhi potensi ikan untuk tumbuh secara maksimal karena konsumsi makanan berhubungan erat denga laju pengosongan perut.(Setiawati dan Suprayudi, 2003)
Menurut (Burhanudin,2012), kualitas pakan dalam hal ini protein berpengaruh sangat nyata terhadap efisiensi pakan dan aktivitas protease ikan gurami. Akselerasi pertumbuhan benih sidat didukung oleh teknologi protein recombinan pertumbuhan (Lubis 2012).

Dari Tabel 1 terlihat bahwa pakan suspensi kijing ini juga memiliki serat kasar yang sangat kecil yaitu $0.08 \%$. serat kasar yang berlebihan akan menghambat pertumbuhan atau mempengaruhi pencemaran media, sebaliknya kandungan serat kasar sedikit akan membuat benih sidat mudah mencerna pakan yang diberikan. Hal ini didukung oleh Parakkasi (1983) yang menyatakan bahwa kadar serat yang tinggi selain akan menurunkan nilai daya cerna suatu pakan, juga menurunkan efisiensi penggunaan pakan. Selanjutnya Huet (1971) menyatakan bahwa pertumbuhan akan terjadi bila jumlah pakan yang dicerna lebih besar dari pada yang diperlukan untuk mempertahankan hidup.

Dosis pemberian pakan 25\% pada tiap perlakuan, hanya pada perlakuan A yang memberikan pertumbuhan yang baik. Hal ini sama dengan yang diperoleh Usui (1991), yang menyatakan bahwa pemberian pakan sidat adalah $25 \%$ dari bobot badanya per hari. Hanya selama pengamatan seperti pakan uji yang lain pakannya tidak terkonsumsi secara baik. Nilai efisiensi pakannya 4.41\%, memacu pertumbuhan sidat yang paling baik. Dikaitkan dengan pernyataan Dirjen Perikanan (1985) menginformasikan bahwa pakan yang baik disyaratkan agar mempunyai nilai efisiensi pakan lebih dari 25\%. Namun justru perlakuan A (pakan suspensi daging kijing Taiwan) yang mempunyai nilai efisiensi pakan 4.41\% mampu memberikan pertumbuhan yang baik bagi sidat. 
Adapun nilai efisiensi pakan itu sendiri bukan merupakan suatu angka yang mutlak karena nilai itu ditemukan juga oleh kualitas pakan serta faktor - faktor lain diantaranya : jenis ikan, ukuran ikan, kualitas air, jumlah dan waktu pemberian pakan serta nutrisi pakan. Kunci keberhasilan suatu usaha budidaya ikan ditentukan oleh kemampuan ikan untuk mencerna dan mengabsorbsi pakan yang diberikan (Dirjen Perikanan, 1985). Jelas bahwa semua faktor yang telah diuraikan di atas saling berkaitan satu dan lainnya dalam menunjang pertumbuhan ikan dengan baik.

\section{SIMPULAN}

Penelitian yang dilaksanakan ini berhasil menyimpulkan bahwa pertumbuhan benih sidat terbaik ditunjukkan oleh perlakuan A, pakan suspensi daging kijing Taiwan, baik untuk pertumbuhan nisbi maupun nilai efisiensi pakan.

\section{DAFTAR PUSTAKA}

Anonim. 1993. Keong Emas (Siput Murei) dan Pengendaliannya, Balai Informasi Pertanian. Departemen Pertanian, Sulut.

Burhannudin. 2012. Efisiensi Pakan dan

Aktivitas Protease Ikan Gurami (Osphronemus),Tesis

UNSOED.
Dirjen Perikanan. 1985. Spesifikasi Teknik

Pakan Udang. Direktorat Jendral Perikanan, Direktorat Bina Produksi. Jakarta 20 Hal.

Huet M. 1971. Tex Book of Fish Culture Fishing New, Ltd. London. 317p

Lubis A. 2012. Akselerasi Pertumbuhan

Benih Ikan Sidat Anguilla bicolor bicolor dengan Teknologi Protein Recombinan Hormon Pertumbuhan. Program PKM Bidang Penelitian.

Matsui I. 1986. Teori and Practice of Eel Culture. Translated From Japanese, A. A. Balkema/ Rotterdam.

Parakkasi A. 1983. Ilmu Gizi dan Makanan Ternak Monogastrik. Penerbit Angkasa Bandung.

Sarwono B. 1997. Budidaya Belut dan Sidat, PT. Penerbit Swadaya, Jakarta

Setiawati M, Suprayudi MA. 2003. Jurnal Akuakultur Indonesia, 2(1)

Sandiver PA, Yoseph JD. 1976. Growth Respon of Juvenile Prawn. Aprpared Ration Augment White Shrimp Head Oil. Aquaculture. P. 129-138.

Sulistijo. 1981. Hal. Ikhwal Tentang Sidat. Pewarta Oseana no. 6 LIPI. Lembaga Oseonologi Nasional, Jakarta.

Usui A. 1991. Eel Culture, Fishing news Books. 